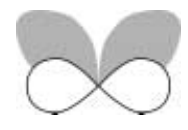

\title{
Dispersal vs. vicariance in the Mediterranean: historical biogeography of the Palearctic Pachydeminae (Coleoptera, Scarabaeoidea)
}

Isabel Sanmartín* Department of Systematic Zoology, Evolutionary Biology Centre, Uppsala, Sweden

\begin{abstract}
Aim The geological evolution of the Mediterranean region is largely the result of the Tertiary collision of the African and Eurasian Plates, but also a mosaic of migrating island arcs, fragmenting tectonic belts, and extending back-arc basins. Such complex paleogeography has resulted in a 'reticulate' biogeographical history, in which Mediterranean biotas repeatedly fragmented and merged as dispersal barriers appeared and disappeared through time. In this study, dispersal-vicariance analysis (DIVA) is used to assess the relative role played by dispersal and vicariance in shaping distribution patterns in the beetle subfamily Pachydeminae Reitter, 1902 (Scarabaeoidea), an example of eastwest Mediterranean disjunction.
\end{abstract}

Location The Mediterranean region, including North Africa, the western Mediterranean, Balkans-Anatolia, Middle East, Caucasus, the Iranian Plateau, and Central Asia.

Methods A phylogenetic hypothesis of the Palearctic genera of Pachydeminae in conjunction with distributional data was analysed using DIVA. This method reconstructs the ancestral distribution in a given phylogeny based on the vicariance model, while allowing dispersal and extinction to occur. Unlike other methods, DIVA does not enforce area relationships to conform to a hierarchical 'area cladogram', so it can be used to reconstruct 'reticulate' biogeographical scenarios.

Results Optimal reconstructions, requiring 23 dispersal events, suggest that the ancestor of Pachydeminae was originally present in the south-east Mediterranean region. Basal splitting within the subfamily was caused by vicariance events related to the late Tertiary collision of the African microplates Apulia and Arabia with Eurasia, and the resultant arise of successive dispersal barriers (e.g. the Red Sea, the Zagros Mountains). Subsequent diversification in Pachydeminae involved multiple speciation events within the Middle East and Iran-Afghanistan regions, which gave rise to the least speciose genera of Pachydeminae (e.g. Otoclinius Brenske, 1896). Finally, the presence of Pachydeminae in the western Mediterranean region seems to be the result of a recent dispersal event. The ancestor of the Iberian genera Ceramida Baraud, 1987 and Elaphocera Gené, 1836 probably dispersed from the Middle East to the Iberian Peninsula across North Africa and the Gibraltar Strait during the 'Messinian salinity crisis' at the end of the Miocene.

Main conclusions Although the basal diversification of Pachydeminae around the Mediterranean appears to be related to vicariance events linked to the geological formation of the Mediterranean Basin, dispersal has also played a very important role. Nearly $38 \%$ of the speciation events in the phylogeny resulted from dispersal to a new area followed by allopatric speciation between lineages. Relationships between western and eastern Mediterranean disjuncts are usually explained by dispersal through Central Europe. The biogeographical history of the Pachydeminae corroborates other biogeographical studies that consider North Africa to be an alternative dispersal route by which Mediterranean taxa could have achieved circum-Mediterranean distributions.

\footnotetext{
*Correspondence: Isabel Sanmartín, Department of Systematic Zoology, Evolutionary Biology Centre, Norbyvägen 18D, 752 36-Uppsala, Sweden.

E-mail: isabel.sanmartin@ebc.uu.se
} 


\section{Keywords}

Mediterranean basin, reticulate biogeographical history, dispersal-vicariance analysis, Scarabaeoidea, Melolonthidae, North-African dispersal, Messinian salinity crisis.

\section{INTRODUCTION}

Dispersal and vicariance are often considered competing hypothesis in historical biogeography. Disjunct distributions can be explained either by fragmentation of widespread ancestors by vicariant (isolating) events or by dispersal across a pre-existing barrier. Most current methods of biogeographical analysis (Nelson \& Platnick, 1978; Brooks, 1990; Page, 1994) are based on the vicariance model because nearly any distribution pattern can be explained by dispersal, making dispersal hypotheses very difficult to falsify (Morrone \& Crisci, 1995).

In the classic vicariant scenario, geographical division of an ancestral area by consecutive dispersal barriers is followed by fragmentation (allopatric speciation) of its inhabiting biota (vicariance). The sequence of vicariant events can thus be directly reconstructed from the organism phylogeny, by simply replacing the name of the taxa for the areas in which they occur. The resulting pattern can be represented in the form of a hierarchical branching diagram, the 'area cladogram', which presumably reflects the biotic relationships among the areas analysed (Morrone \& Crisci, 1995). The vicariance model does not incorporate dispersal except to explain the origin of the widespread ancestral distribution, i.e. all dispersal events occurred before the first split in the phylogeny. Dispersal within the cladogram is only considered a posteriori in interpreting incongruence between the area cladogram and a particular biogeographical scenario (Ronquist, 1997).

Recent paleogeographical reconstructions, however, indicate that many regions present a more complicated geological history than a simple sequence of vicariant landmasses. For instance, some of the Southern Hemisphere landmasses were formed trough the accretion of multiple terranes and present a 'composite' biogeographical history (Sanmartín \& Ronquist, in press). The Northern Hemisphere region conforms to what has been termed a 'reticulate' biogeographical scenario (Ronquist, 1997). From the Mesozoic period onwards, the Holarctic landmasses became separated and joined to each other in different combinations over time, as dispersal barriers like mid-oceanic seaways or mountain chains, appeared and disappeared through time (Smith et al., 1994). This has resulted in a pattern of 'reticulate' area relationships, in which repeated episodes of vicariance and dispersal have affected the same areas at different times (Sanmartín et al., 2001). These patterns are not expected to conform to the classic vicariant scenario and cannot be represented in the form of a simple branching area cladogram.

On the other hand, the advent of molecular-based phylogenies in the last decades has strengthened the role of dispersal as a primary process in the development of concordant distribution patterns (Voelker, 1999, 2002). Estimates of divergence times based on the molecular clock can be used to roughly correlate the timing of species cladogenesis with the timing of vicariant (paleogeographical) events. In many cases, this has shown that the group studied is too young to have been affected by the presumed vicariant barrier, suggesting a recent history of dispersal, rather than vicariance, for these taxa (Voelker, 1999; Waters et al., 2000; Sanmartín \& Ronquist, in press, and references therein).

Recently, new methods of biogeographical reconstruction have been proposed in which both dispersal and vicariance are allowed (Page, 1995; Ronquist, 1997, 1998, 2002; Sanmartín \& Ronquist, 2002). These 'event-based' methods reconstruct the pattern of ancestral distributions, by explicitly incorporating biogeographical processes into the analysis. Each of these processes (vicariance, dispersal, extinction, and sympatric speciation) is associated with a cost that should be inversely related to its likelihood: the more likely the event, the lower the cost. The optimal reconstruction is found by searching for the reconstruction that minimizes the total cost of the implied events (Ronquist, 1998, 2002). Thus, the minimum-cost reconstruction is the most likely (most parsimonious) explanation for the origin of the pattern being analysed. Because the optimality criterion being used is one of maximum parsimony, these methods are often called 'event-based parsimony methods'.

In this study, I used 'dispersal-vicariance analysis' (DIVA) (Ronquist, 1996, 1997), an event-based parsimony method, to reconstruct the biogeographical history of the subfamily Pachydeminae Reitter, 1902 (Coleoptera, Scarabaeoidea) in the Mediterranean region. Dispersal-vicariance analysis reconstructs ancestral distributions in a given phylogeny assuming a vicariance model, while at the same time allowing for dispersal and extinction to occur (Ronquist, 1997). However, unlike other biogeographical methods, DIVA does not enforce area relationships to conform to a hierarchical 'area cladogram', so it can be used to address 'reticulate' biogeographical scenarios. The latter property is essential when reconstructing the biogeographical history of the Mediterranean region. The Mediterranean Basin was formed during the Tertiary, as a result of the interaction between the African and Eurasian Plates, and several associated African microplates: Iberia, and the two main African Promontories: Apulia and Arabia (Dewey et al., 1973; Dercourt et al., 1986; Krijgsman, 2002). The western part of the Mediterranean region (Iberia, France, part of southern Italy) was probably formed in the early Tertiary (Eocene, $35 \mathrm{Myr}$ ), as a result of the collision of the Iberian and Apulian Plates with Eurasia. The eastern Mediterranean 
region (Hellenic arc and Aegean basin) is of more recent date: the result of the collision of the Arabian Plate with a stable Eurasia during the mid-Miocene (16 Myr) (Krijgsman, 2002). The opposite pattern can be found between the Mediterranean basins. The eastern Mediterranean Sea (Ionian and Levantine basins) is composed of ocean seafloor floored during the Jurassic-Cretaceous period as a result of the counterclockwise rotation of Apulia about a pole near Tunisia. The western Mediterranean Sea (Alboran, Balearic, and Tyrrhenian basins), in contrast, was floored during the late Oligocene-early Miocene, following a second rotation of Apulia about a more distant pole, which produced convergence with both Iberia and Eurasia (Dewey et al., 1973; Dercourt et al., 1986).

Some paleogeographical reconstructions suggest that a landmass connection existed across the Mediterranean at various times during the Oligocene-Miocene, which separated the Tethys (proto-Mediterranean) from the Paratethys, allowing biotic dispersal over the region (Rögl \& Steininger, 1983; Oosterbroek \& Arntzen, 1992). Each of these 'regression-dispersal' events was followed by a new marine transgression that restored connections between the Tethys and Paratethys, and resulted in east-west vicariance of transMediterranean lineages (Oosterbroek \& Arntzen, 1992). Regression (dispersal) and transgression (vicariance) cycles, as well as a mosaic of migrating island arcs, extensional basins, and fragmenting tectonic belts, have resulted in a 'reticulate' biogeographical history, in which Mediterranean biotas repeatedly fragmented and merged as dispersal barriers appeared and disappeared through time (Oosterbroek \& Arntzen, 1992; Martín-Piera \& Sanmartín, 1999). Many Mediterranean taxa present disjunct distributions between the west and east Mediterranean, or, on a larger scale, between the western Mediterranean and Central Asia, the so-called 'Kiermack' disjunctions (Ribera \& Blasco-Zumeta, 1998), with a high number of endemics in northwest Africa, Iberia, the Mediterranean Islands, Balkans-Anatolia, the Middle East, and the trans-Caucasus (Oosterbroek \& Arntzen, 1992; Ribera \& Blasco-Zumeta, 1998; MartínPiera \& Sanmartín, 1999, and references therein). These disjunct biogeographical patterns are probably the result of the complex (reticulate) paleogeographical history of the present Mediterranean region.

The beetle subfamily Pachydeminae Reitter, 1902 (Scarabaeoidea, Melolonthidae) is an excellent tool with which to investigate the biogeographical history of the Mediterranean region. The Pachydeminae comprise about 530 species worldwide (Lacroix, 2000), and have a cosmopolitan but very disjunct distribution. Within the Holarctic region, they are present in western North America (California and Mexico) and the southern Palearctic. In the latter region, they present a 'Turanian-Mediterranean' distribution (sensu Ribera \& Blasco-Zumeta, 1998), with disjunctions between the West and East Mediterranean regions (e.g. genus Elaphocera Gené, 1836), and between the western Mediterranean and Central Asia (see discussion). Most species of Pachydeminae are characterized by their low dispersal ability (females are flightless), and reduced geographical ranges.
These characteristics (disjunct distributions and high endemicity) make the Pachydeminae an especially suitable group with which to study the relative importance of history in the shaping of biogeographical patterns (Noonan, 1988).

As in the rest of Melolonthidae subfamilies (Browne \& Scholtz, 1999), phylogenetic relationships within the Pachydeminae are poorly resolved. Recently, Sanmartín \& Martín-Piera (2003) reviewed the systematics of the Palearctic genera, and proposed the first phylogenetic hypothesis within the subfamily. In this study, I used this phylogenetic hypothesis, in conjunction with DIVA, to reconstruct the biogeographical history of the Palearctic Pachydeminae. In particular, I wanted to assess the relative role played by dispersal and vicariance in the shaping of present biogeographical patterns in the subfamily. This is the first time DIVA is used to reconstruct the biogeographical history of a group of Mediterranean organisms.

\section{MATERIAL AND METHODS}

\section{Areas of analysis}

The Palearctic Pachydeminae comprise about 20 genera and 300 species, although there is not a definitive inventory (Lacroix, 2000). They are distributed across southern Eurasia from the Canary Islands to China, including North Africa, southern Europe (except France and Italy), Asia Minor, Middle East, Iran, Afghanistan, Caucasus, and Central Asia (Sanmartín \& Martín-Piera, 2003). The majority of species occur in the southwest Palearctic (west of the Ural Mountains) around the Mediterranean region, with the eastern Palearctic only represented by a few species of Tanyproctus Faldermann, 1835 in China (Lacroix, 2000). Sanmartín \& Martín-Piera's (2003) analysis included 49 species representing 16 Palearctic genera, among them the most widespread and largest Palearctic genera: Tanyproctus; Pachydema Castelnau, 1832; Hemictenius Reitter, 1897; Ceramida Baraud, 1987, and Elaphocera Gené, 1836 (89\% of the total Palearctic species, see Table 1). Each genus was represented by a sample of species reflecting their morphological and geographical diversity. The Appendix shows the distribution of each of the included species. The rest of Palearctic genera not included in the analysis (see Table 1) are all monotypic or small, recently described genera (Sanmartín \& Martín-Piera, 2003). Sanmartín \& MartínPiera's (2003) original study did not include any of the Chinese species of Pachydeminae. The distribution of these species is very disjunct with respect to the rest of the subfamily, and they have often been considered as part of the Oriental fauna. Also, their status within Pachydeminae is uncertain. They are currently assigned to Tanyproctus, a polyphyletic genus that needs to be redefined (Sanmartín \& Martín-Piera, 2003). Nevertheless, a new phylogenetic analysis would be necessary to establish whether these Chinese species form an independent group or are derived from one of the Palearctic clades.

There is still an ongoing debate about the definition of areas of endemism in historical biogeography (Harold \& 
Table I Distribution of the Palearctic genera of the subfamily Pachydeminae Reitter, 1902 included in this study. The distributions follow the regions defined in Fig. 1

\begin{tabular}{|c|c|c|}
\hline Genus & Distribution & $\mathrm{N}^{\circ}$ Species \\
\hline Pachydema Castelnau, 1832 & North Africa (A), Canary Islands (B) & 98 \\
\hline Tanyproctus Faldermann, 1835* & $\begin{array}{l}\text { North Africa (A), eastern Mediterranean (D), } \\
\text { Middle East (E), Caucasus region (F), } \\
\text { Iran-Afghanistan }(\mathrm{G}) \text {, Central Asia (H) }\end{array}$ & 90 (Approx.) \\
\hline Hemictenius Reitter, 1897 & Central Asia $(\mathrm{H})$ & 25 \\
\hline Elaphocera Gené, 1836 & $\begin{array}{l}\text { Northwest Africa (A), western } \\
\text { Mediterranean (C), } \\
\text { eastern Mediterranean (D), Middle East (E) }\end{array}$ & 43 \\
\hline Ceramida Baraud, 1987 & $\begin{array}{l}\text { Northwest Africa (A), } \\
\text { western Mediterranean (C) }\end{array}$ & 11 \\
\hline $\begin{array}{l}\text { Leptochristina Baraud } \\
\text { \& Branco, } 1991\end{array}$ & Middle East (E) & 4 \\
\hline Otoclinius Brenske, 1896 & Iran-Afghanistan $(\mathrm{G})$ & 5 \\
\hline Atanyproctus Petrovitz, 1954 & Iran-Afghanistan $(\mathrm{G})$ & 6 \\
\hline Alaia Petrovitz, 1980 & Iran-Afghanistan $(\mathrm{G})$ & 1 \\
\hline Brenskiella Berg, 1898 & Middle East (E) & 1 \\
\hline Europtron Marseul, 1867 & North Africa (A) & 3 \\
\hline $\begin{array}{l}\text { Kryzhanovskia Nikolajev } \\
\quad \text { \& Kabakov, } 1977\end{array}$ & Iran-Afghanistan $(\mathrm{G})$ & 1 \\
\hline Pachydemocera Reitter, 1902 & Eastern Mediterranean (D), Middle East (E) & 1 \\
\hline Peritryssus Reitter, 1918 & Sicily (I) & 1 \\
\hline $\begin{array}{l}\text { Pseudopachydema Balthasar, } \\
1930\end{array}$ & Caucasus (F) & 1 \\
\hline Tanyproctoides Petrovitz, 1971 & Middle East (E) & 1 \\
\hline
\end{tabular}

*Tanyproctus is also present in China (see text).

Palearctic genera not considered in this study (Lacroix, 2000): Phalangonyx Reitter 1889, Jalalabadia Balthasar, 1967, Buettikeria Sabatinelli \& Pontuale, 1998, Asiactenius Nikolajev, 2000 (see text).

Mooi, 1994; Cox, 2001; Linder, 2001; Morrone, 2002). Here, an area of endemism is defined as a congruent distributional range (sympatric distribution) shared by two or more species (except for Sicily, which is only defined by the distribution of Peritryssus excisus Reitter, 1918; see below). Where possible, however, areas were also defined by geographical boundaries, such as the existence of geological features that could have acted as barriers to dispersal. For instance, the Middle East (area E) is separated from Iran (area G) by the Zagros Mountains, whereas the Red Sea and the Isthmus of Suez mark the geographical boundary between the Middle East and North Africa (area A).

According to these criteria, nine areas were considered in the analysis (Fig. 1; Table 1).

(A) North Africa: extending from the Atlantic Ocean (Morocco) to the Red Sea (Egypt, including the Sinai Peninsula). Pachydema is the most speciose genus in this region (82 species), but a few species of Elaphocera (e.g. E. sulcatula Fairmaire, 1884), Ceramida [e.g. C. mauritanica (Rambur, 1843)], and Tanyproctus [e.g. Tanyproctus bicuspidatus (Peyerimhoff, 1926)] can also be found in the coasts of North Africa. Europtron Marseul, 1867 (three species) is also endemic to this region. The majority of species of Pachydeminae are endemic to Northwest Africa (Morocco, Algeria, and Tunisia). This is reflected in the analysis by the predominance of northwest African species (8) against one northeast species [P. palposa Reitter, 1902
(Egypt), Appendix]. I considered North Africa, however, as a single unit in the analysis for two reasons. First, the two main African genera, Pachydema and Tanyproctus, are also present in Northeast Africa. About 10 species of Pachydema are endemic to Egypt, and four more are present in Lybia (e.g. P. obscurata Fairmaire, 1883). Two species of Tanyproctus occur in Egypt (e.g. T. indescriptus Baraud, 1979) against one in Morocco (T. bicuspidatus). Second, almost all species of Pachydema endemic to Libya are also present in Tunisia, indicating that there is no clear separation between these two regions. Probably, the paucity of species in Libya is simply the result of lack of sampling or extinction occurred during the formation of the Libyan Desert. More species of Pachydeminae are likely to be found in Lybia.

(B) The Canary Islands: sixteen species of Pachydema are endemic to the Canary Archipelago.

(C) Western Mediterranean region: including the Iberian Peninsula and the south-western Mediterranean Islands (the Balearic Archipelago and Sardinia). Numerous species of Ceramida and Elaphocera are endemic to this region. Curiously, no species of Pachydeminae are found in the Central Mediterranean, i.e. southern France and the Italian Peninsula.

(D) Eastern Mediterranean region (Balkans/Anatolia): including Greece, the Aegean Islands, Crete, Rhodes, and the Anatolian Peninsula (Asia Minor). Elaphocera with 10 species is the most speciose genus in this region, which also 
Figure I Areas of distribution of the Palearctic genera of Pachydeminae Reitter, 1902 as defined in this study. A, North Africa, B, Canary Islands, C, western Mediterranean (Iberian Peninsula and south-western Mediterranean islands), D, eastern Mediterranean (Balkans/Anatolia and south-eastern Mediterranean Islands), E, Middle East, F, Caucasus region, G, Iran-Afghanistan, H, Central Asia, I, Sicily.

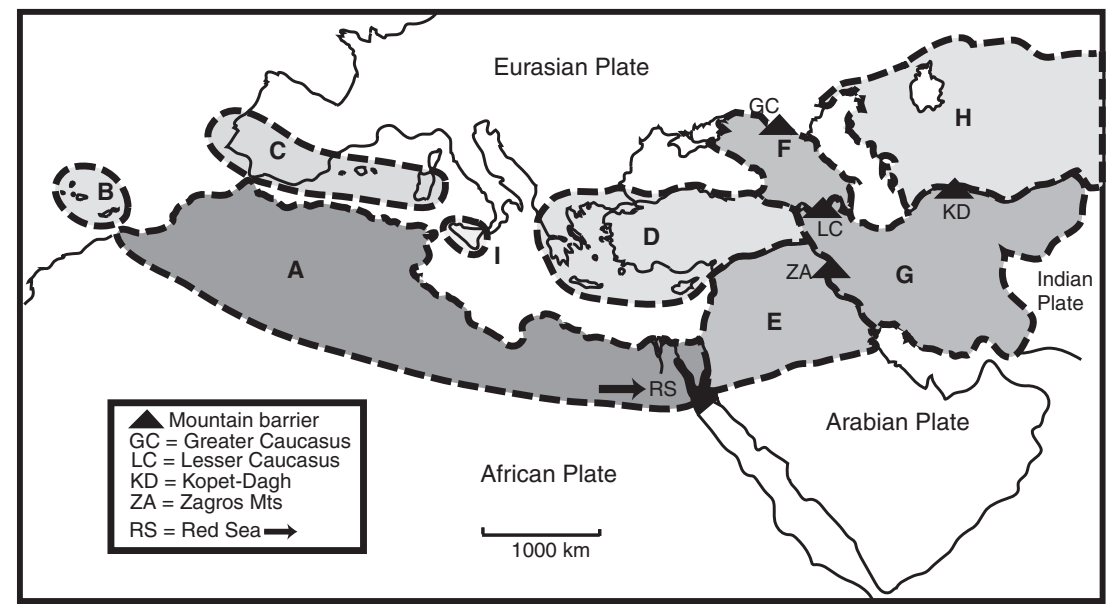

includes a few species of Tanyproctus [e.g. T. reichei (Rambur, 1843)]. The Balkans and the Anatolian Peninsula are considered here as one region because the Bosporus Strait was not opened until the end of the Pliocene, and the fauna of both sides is usually very similar (Cheylan, 1995). Several species of Pachydeminae are widespread in Greece and Turkey [e.g. T. reichei; E. gracilis (Waltl, 1838)].

(E) Middle East: defined as the northern part of the Arabian Plate, including the Levant region (Syria, Israel, and Jordan), Iraq, and northern Saudi Arabia. There are several small genera of Pachydeminae endemic to this region (e.g. Leptochristina Baraud \& Branco, 1991, Pachydemocera Reitter, 1902 (synonymy of Elaphocera, Sanmartín \& Martín-Piera, 2003), Brenskiella Berg, 1898, Tanyproctoides Petrovitz, 1971), as well as numerous species of Tanyproctus (e.g. T. rugulosus Fairmaire, 1892), and Elaphocera syriaca Kraatz, 1882. A few species of Pachydema are also found in this area (e.g. P. abeillei Fairmaire, 1881, Lacroix, 2000).

(F) The Caucasus region: including the republics of Georgia, Azerbaijan, and Armenia. The Lesser Caucasus Mountains in the south, the Greater Caucasus in the north, the Black Sea on the west, and the Caspian Sea on the east are the geographical boundaries of this region. Nearly all species of Pachydeminae present in the Caucasus region (all belonging to genus Tanyproctus) are also widespread in Iran (area G). The monotypic Pseudopachydema Balthasar, 1930 is the only genus of Pachydeminae endemic to the Caucasus.

(G) Iran-Afghanistan: This region is delimited by the Zagros Mountains in the southwest, the Kopet-Dagh and Lesser Caucasus Mountains in the north, and the Indian Plate (Pamir Mountains) in the east. Many small genera of Pachydeminae (Atanyproctus Petrovitz, 1954, Alaia Petrovitz, 1980, Otoclinius Brenske, 1896, and Kryzhanovskia Nikolajev \& Kabakov, 1977) and numerous Tanyproctus species [T. persicus (Ménétries, 1832)] are endemic to this region.

(H) Central Asia: Defined as the Turanian or trans-Caspian region, and including the republics of Turkmenistan, Uzbekistan, Tajikistan, Kirzigistan, and Kazakhstan.
Hemictenius is the only genus endemic to this region, although a few species of Tanyproctus occurring in IranAfghanistan are also widespread in Central Asia [e.g. T. bucharicus (Reitter, 1897)].

(I) Sicily: Peritryssus excisus is the only species of Pachydeminae present in Sicily. Because of its atypical morphology (Sanmartín \& Martín-Piera, 2003), and the geographical isolation of Sicily, I considered this region as a separate area, instead of part of the western Mediterranean.

\section{Phylogenetic hypothesis}

Sanmartín \& Martín-Piera (2003) obtained 32 most parsimonious trees (MPTs) of 284 steps $(\mathrm{CI}=0.35, \mathrm{RI}=0.77$ ), whose strict consensus is shown in Fig. 2. DIVA can only handle fully bifurcate trees. Ronquist's (1996) suggestion to work with the original trees, from which the consensus is calculated, was not followed here because of the large number of possible trees (32). Instead, the ancestral distributions were inferred from one of the 32 MPTs (Fig. 3), although biogeographical conclusions were only based on those biogeographical events supported by the consensus tree.

Although Sanmartín \& Martín-Piera's strict consensus tree (Fig. 2) shows E. syriaca and E. barbara Rambur, 1843 in a tetratomy with Ceramida and the remaining species of Elaphocera, a more complete analysis involving all species of Elaphocera and Ceramida (in prep.) shows that E. barbara is the sister group to Ceramida and that E. syriaca is the most basal species among the remaining species of Elaphocera. This topology has been adopted in the biogeographical analysis presented below (Fig. 3). It should also be noted that the genus Tanyproctus (the most widespread in the subfamily, Table 1) is polyphyletic (Sanmartín \& MartínPiera, 2003). Some species [T. reichei, T. ganglbaueri (Brenske, 1897), T. saulcyi (Reiche, 1856)] are more closely related to other genera than to the remaining Tanyproctus, and relationships among the rest of species are not resolved (Fig. 2). Biogeographical conclusions in this part of the cladogram should therefore be taken with caution. 


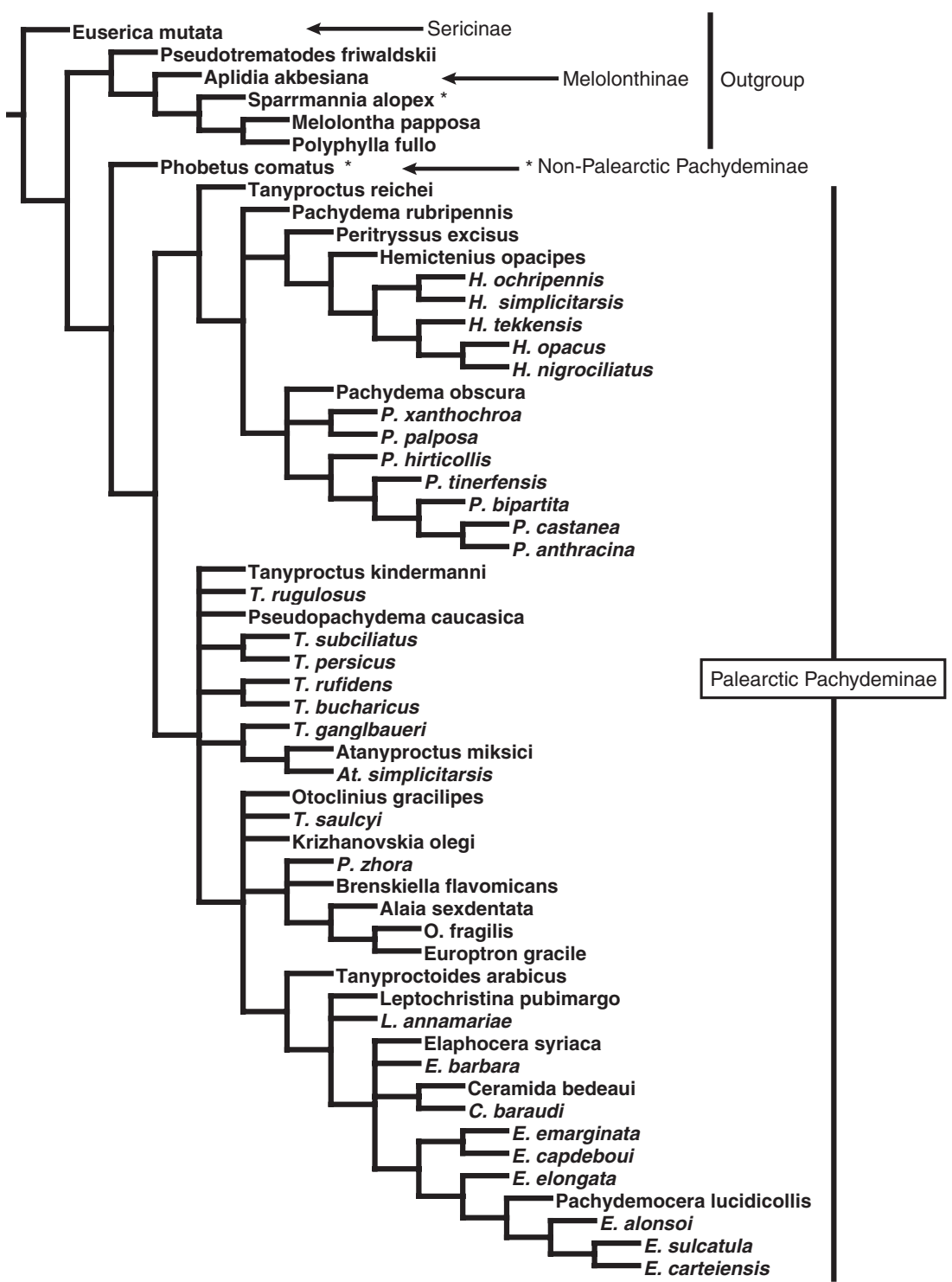

Figure 2 Phylogeny of the Palearctic Pachydeminae Reitter, 1902 (After Sanmartín \& Martín-Piera, 2003). Strict consensus of 32 most parsimonious trees (MPTs) of 284 steps $(\mathrm{CI}=0.35 ; \mathrm{RI}=0.77)$.

\section{Analysis}

Dispersal-vicariance analysis (Ronquist, 1997), as implemented in the computer program DIVA v. 1.1 (Ronquist, 1996), was used to reconstruct ancestral distributions on the phylogeny of Pachydeminae (Fig. 3). This method searches for the optimal reconstruction of ancestral distributions by assuming a vicariant explanation (i.e. allopatric speciation) but at the same time incorporating the potential contribution of dispersal and extinction in shaping the current distributional pattern. In DIVA, vicariance events (allopatric speciation) and duplication events (sympatric speciation, i.e. speciation within the area) carry a cost of zero, whereas dispersal and extinction events cost one per unit area added or deleted from the distribution (Ronquist, 1996). The optimal solutions are those that minimize dispersal and extinction events under a parsimony criterion. This is because both dispersal and extinction are unpredictable events that can wipe out the traces of 'phylogenetically constrained processes' like vicariance and duplication. Thus, spurious events will be introduced in optimal reconstructions unless extinctions and dispersals carry a cost (Ronquist, 1998; Sanmartín \& Ronquist, 2002). Unlike other biogeographical methods, DIVA does not rely in area cladograms, and reconstructs ancestral distributions in a given phylogeny without any prior assumptions about area relationships. Thus, it can be used to reconstruct 'reticulate' biogeographical scenarios (Ronquist, 1996,1997), such as the Mediterranean region.

One drawback of DIVA is that ancestral area optimizations become less reliable as one approaches the root node. This uncertainty is manifested in DIVA as a tendency for the root node distribution to be large and include most of the areas occupied by the terminals (Ronquist, 1996). One 
Figure 3 Summary of the optimal reconstructions of ancestral distributions of the Palearctic Pachydeminae using dispersalvicariance analysis (DIVA). The phylogeny is one of the 32 MPTs in Sanmartín \& MartínPiera (2003). At each node, the optimal distribution is given; alternative, equally optimal distributions are separated with slash marks. Each reconstruction requires 23 dispersal events. When the sequence of dispersal events differs among the reconstructions (e.g. within Elaphocera Gené, 1836, see text), only one is given in the figure. Symbols: circle: vicariance event; rhomb: duplication (sympatric speciation) event; arrow (+): dispersal event. Only unambiguous events are indicated in the reconstruction. $(*)$ : Nodes where extinction events were inferred because the subsequent vicariance event takes place between areas that are not geographically adjacent (Fig. 1).

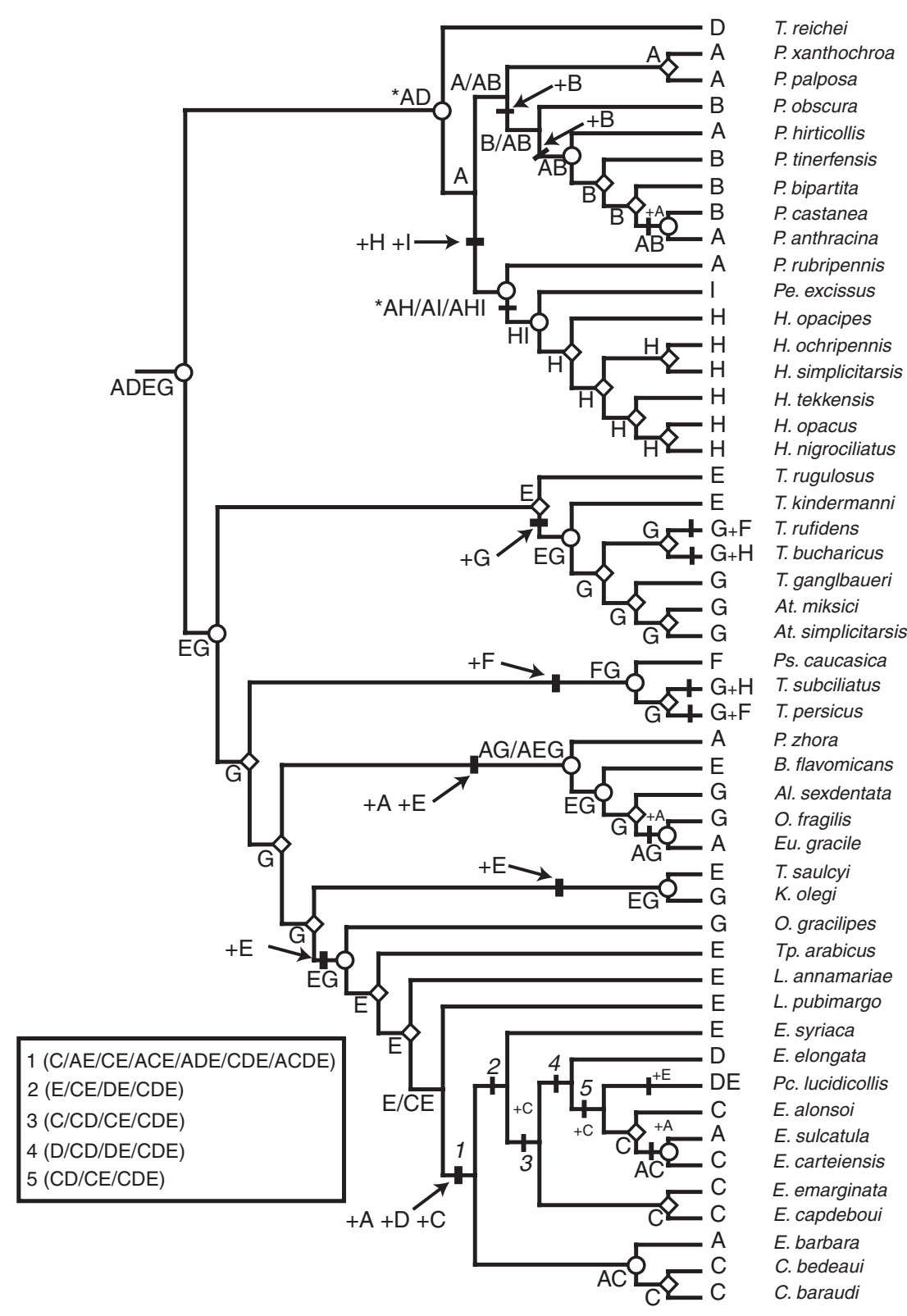

way to solve this is to incorporate additional outgroups into the analysis that can help to restrict the distributions in the root node. However, the closest outgroup in Sanmartín \& Martín-Piera's (2003) phylogeny (Fig. 2) is the genus Phobetus Le Conte, 1856, a Nearctic Pachydeminae, so it cannot be used to constrain the ingroup distribution. Another way is to impose constraints on the maximum number of unit areas allowed in ancestral distributions (using the 'maxareas' option of the 'optimize' command in DIVA). This is equivalent to asking the question: if this group has a restricted distribution in the past (a 'centre of origin'), what would be the most likely ancestral area distribution of the group? If we assume that the dispersal ability of the ancestors (i.e. their ability to achieve a widespread distribution while maintaining species integrity) was not higher than that of the descendants, we could constrain the maximum number of areas in ancestral distributions to the number of areas in the distribution of the most widespread extant descendant. In Pachydeminae, this would imply to restrict the ancestral distributions to two unit areas, which is the distribution of the most widespread terminal species in Fig. 3.

First, I used the exact search of DIVA without restricting the number of areas in which the ancestor occurred, i.e. admitting the possibility of a widespread ancestor. Not surprisingly, the ancestral area reconstruction at the root node included all the areas analysed except the western Mediterranean (C): ABDEGHI/ABDEFGHI. It appears, 
however, unlikely that the ancestor of the Palearctic Pachydeminae occurred in such a widespread distribution, covering the southern Palearctic from Morocco to the Aral-Caspian plains, while at the same time developing a long series of apomorphic features (Nordlander et al., 1996). Moreover, three of the eight areas included by DIVA in the root-node distribution are unlikely to have been part of the ancestral distribution of Pachydeminae. The Canary Islands (B) is a young volcanic archipelago that has probably never been connected to the mainland (Juan et al., 2000). The Caucasus region $(\mathrm{F})$ is usually part of a more widespread distribution involving the Middle East or Iran (i.e. no endemics), suggesting that this area of distribution is probably the result of recent dispersal. Also, Sicily (I) is only inhabited by one species of Pachydeminae ( $P$. excisus), which appears nested within one of the clades (Fig. 3), so it is unlikely to have been part of the ancestral area.

On the other hand, the disjunct distribution and reduced geographical ranges of most species of Pachydeminae suggest that they are not good dispersers and that vicariance is still the main explanation for the biogeographical relationships within the subfamily. Therefore, to assume that the group arose in a small area, a 'centre of origin', from which it dispersed to other areas (i.e. limiting the ancestral distributional range to two unit areas, the distribution of the most widespread species of Pachydeminae), is unrealistic. Therefore, I decided to carry out a constrained analysis (Fig. 3), setting the maximum number of unit areas in ancestral distributions to four, arbitrarily chosen as an intermediate value.

\section{RESULTS AND DISCUSSION}

A DIVA 'constrained' exact search limiting ancestral distributions to no more than four areas resulted in 936 alternative, equally optimal reconstructions, each requiring 23 dispersals between the areas. The optimal area reconstructions at each ancestral node are summarized in Fig. 3.

Despite the high number of alternative reconstructions, they are all very similar, only differing in the ancestral distributions at some distal nodes (e.g. Elaphocera, Fig. 3). All reconstructions postulate the existence of a widespread Palearctic ancestor of Pachydeminae, distributed in the southeast Mediterranean region, including North Africa (A), the eastern Mediterranean (D), the Middle East (E), and the Iran-Afghanistan region (G). Therefore, the presence of Pachydeminae in areas such as the western Mediterranean (C), the Canary Islands (B), the Caucasus (F), Central Asia $(\mathrm{H})$, or Sicily $(\mathrm{I})$, is considered to be the result of subsequent dispersals from the ancestral distribution.

The first three basal nodes correspond to vicariance events (Fig. 3). The most basal vicariance event (AD/EG) separated the ancestor of Pachydema-Hemictenius-T. reichei on North Africa and the eastern Mediterranean region (AD) from the remaining part of the Palearctic Pachydeminae on the Middle East-Iranian Plateau (EG). How old is this first split? No fossils are known of the subfamily Pachydeminae, but the main divisions of Scarabaeoidea were distinct from the beginning of the Tertiary, and the oldest fossil record assigned to Melolonthidae (Eophyllocerus) is from the Eocene (Browne \& Scholtz, 1999). Thus, the Pachydeminae are probably not older than the early mid-Tertiary. However, in order to date more accurately this first split (North Africa/ Iran-Middle East), paleogeographical evidence is needed.

Paleogeographical reconstructions indicate that the geological evolution of the Mediterranean region was largely the result of the convergence of the African and Eurasian Plates during the Tertiary. In the mid-Jurassic (180 Myr), following the opening of the central North Atlantic between North America and Africa, the African Plate started to rotate counterclockwise towards a stable Eurasia. First, Africa moved continuously in an eastern direction but in the late Cretaceous (95 Myr), Africa's motion changed to a north-eastern directed compression (Dercourt et al., 1986; De Jong, 1998). During this convergence, the old Jurassic Tethys Ocean that originally separated the African and Eurasian Plates was completely eliminated and replaced by a new ocean, the Mesogean or protoMediterranean. During the Eocene, continental collision between the African and Eurasian Plates increased, and was dominated by the interaction of Eurasia with three associated African microplates: Iberia, and the two main African Promontories of Apulia and Arabia (Dewey et al., 1973; Dercourt et al., 1986).

The Iberian microplate was part of Africa from the late Cretaceous until the Eocene (110-154 Myr), when it began to move northwards, eventually colliding with Eurasia in the late Eocene (35 Myr). The collision gave rise to the first Pyrenees. Apulia detached from Africa in the early Cretaceous (130 Myr), becoming an independent microplate until the late Cretaceous ( $80 \mathrm{Myr}$ ), after which, it behaved again as an African Promontory. Its final collision with Eurasia in the Eocene (35 Myr) initiated the deformation of the Alpine orogenic system (Dercourt et al., 1986).

At the end of the Cretaceous-early Paleocene (60 Myr), the Arabian Plate began to separate from the main African Plate along the line of the Red Sea and Gulf of Aden (Thompson, 2000). When it was first formed, the Red Sea was only a chain a lakes at the deepest parts of the valley. The rifting process continued during the early Tertiary until a connection with the Mediterranean Sea was developed during the Eocene (40 Myr), which cut off the terrestrial connections between Africa and Arabia in the north (Thompson, 2000). A second phase of rifting began in the early Pliocene (5 Myr), when the uplift of the Isthmus of Suez finally cut off the Red Sea from the Mediterranean, and opened it to the Indian Ocean through the Gulf of Aden. Thus, the opening of the Red Sea and the Gulf of Aden mark the tectonic boundary between the African and Arabian Plates.

It is possible that the split between the ancestor of T. reichei-Pachydema-Hemictenius in North Africa (Anatolia) and the rest of Pachydeminae in the Middle EastIran (AD/EG) corresponds to the time when the Arabian Plate and the African Plate became separated along the line of the Red Sea. Either the early Tertiary connection between the Red Sea and the Mediterranean, or the uplift of the 
Isthmus of Suez in the early Pliocene, could have acted as vicariance events, responsible for the interruption of terrestrial connections between North Africa and Arabia (West Asia). This explanation agrees well with other biogeographical studies on southwest Palearctic groups that consider the opening of the Red Sea responsible for evolutionary divergences between African and Arabian (West Asian) lineages (Doadrio, 1990, Cheylan, 1995; Doadrio et al., 1998; Zardoya \& Doadrio, 1998). The origin of the Saharan and Arab-Syrian deserts during the late Miocene-Pliocene (6 Myr) could also have acted as additional barrier to dispersal between North Africa and West Asia; these deserts presently mark the natural boundary between the Ethiopian and temperate Palearctic biotas (Por, 1975). However, these events can only explain the vicariance between Arabia-West Asia and North Africa (A/EG), but not the vicariance with the Balkans-Anatolian region (D). According to Thompson (2000), as the Arabian Plate broke away from Africa in the early Tertiary, it began to move northeastwards, colliding with the Eurasian Plate in the mid-Miocene, $16 \mathrm{Myr}$ ago (Krijgsman, 2002). One result of this collision was the westward squeezing of the Turkish Plate along the Anatolian Fault Zone, and its lateral extrusion away from the ArabiaEurasia collision zone (Dercourt et al., 1986; Krijgsman, 2002). It is possible that this event isolated the BalkansAnatolian region (D) from the Middle East-Iranian Plateau (EG), as indicated in the first vicariance (AD/EG, Fig. 3).

It is, however, more difficult to explain the wide disjunct distribution of the clade $T$. reichei-PachydemaHemictenius prior to the vicariance, which includes North Africa (Pachydema-Hemictenius) and the eastern Mediterranean region (T. reichei): (AD, Fig. 3). Turkey, as well as Iran and Afghanistan, was derived from a Gondwanan microplate that rifted off from the margin of Gondwana during the early Triassic and collided with Eurasia during the Cretaceous. By the early Tertiary, these blocks were already part of the south-eastern margin of the Eurasian Plate (Dewey et al., 1973; Dercourt et al., 1986). MartínPiera \& Zunino $(1983,1985)$ explain the close relationship between North African an Anatolian lineages that has been found in several Scarabaeidae genera as the result of a connection between North Africa and Anatolia that was established at the beginning of the Tertiary, after the late Cretaceous collision of the Apulian Plate with Eurasia. These events, however, are probably too old to explain the wide disjunction North Africa/Anatolia observed in the clade $T$. reichei-Pachydema-Hemictenius. It is more likely that the present disjunct distribution is the result of the extinction of this clade in the intermediate areas (e.g. the Levant region, see below).

According to paleogeographical reconstructions (Rögl \& Steininger, 1983 in Oosterbroek \& Arntzen, 1992: Fig. 16D, p. 12), biotic exchange between Europe and North Africa across the Mediterranean became possible during the Middle Miocene (14-13 Myr) through a continuous landmass separating the Tethys from the Paratethys, and roughly corresponding to the Balkans/Anatolian (+Levant) region. This connection was interrupted in the late Miocene $(10 \mathrm{Myr}$ ago), when final structuring of the Alps and a new marine transgression between the Tethys and Paratethys in the east isolated the Balkans/Anatolian block from the rest of the Mediterranean region. The biogeographical reconstruction in Fig. 3 indicates a vicariance event between T. reichei in the eastern Mediterranean region (Balkans-Anatolia) and the stem species of Pachydema- Hemictenius in North Africa. It is possible that T. reichei is the only survivor of a lineage that was originally present in the eastern Mediterranean (D) and became isolated by this late Miocene marine transgression from the ancestor of Pachydema-Hemictenius in North Africa (A). Vicariance events between the ancestor of Balkans/Asia Minor lineages and the ancestors of transMediterranean lineages have been documented in several other Mediterranean groups (Oosterbroek \& Arntzen, 1992, Martín-Piera \& Sanmartín, 1999). Alternatively, the distribution of $T$. reichei could be the result of more recent dispersal from North Africa and the Levant. However, the first possibility, the relict character of $T$. reichei, agrees better with Sanmartín \& Martín-Piera's (2003) indication that this species is atypical in its morphology, with numerous apomorphies (mouthparts, genitalia) that separate it from the rest of Tanyproctus.

The third vicariance event $(\mathrm{E} / \mathrm{G})$ isolated the ancestor of a clade including Atanyproctus and several Tanyproctus species, in the Middle East region (E), from the remaining part of the subfamily in the Iran-Afghanistan Plateau (G). Paleogeographical reconstructions indicate that the Miocene collision of the Arabian Plate against Eurasia resulted in the uplifting of several mountain belts surrounding the Iranian Plateau (Dercourt et al., 1986). The first to be uplifted were the Zagros Mountains in southern Iran (10 Myr), which now mark the tectonic boundary between the Arabian and Eurasian Plates. As the Arabian Plate continued its indentation into Eurasia, a second phase of uplifting in the early Pliocene $(5 \mathrm{Myr})$ resulted in the rise of mountain chains in northern Iran: the Kopet-Dagh and Lesser Caucasus Mountains (Dercourt et al., 1986). These mountain belts now mark the geographical boundary between Iran and the Central Asia and Caucasus regions, respectively. This sequence of mountain uplifting events has often been suggested as an explanation for evolutionary divergences found in southwest Palearctic taxa between Iranian and Arabian lineages (Zagros Mountains), and between Iranian and Central Asian/Caucasian lineages (Kopet Dagh and Lesser Caucasus Mountains) (Cheylan, 1995; Macey et al., 1998; Martín-Piera \& Sanmartín, 1999).

The DIVA ancestral area reconstructions postulate that the ancestor of Pachydema-Peritryssus-Hemictenius was originally present in North Africa, where it underwent duplication (speciation within the area), and gave rise to two different lineages. One of them, the ancestor of the genus Pachydema, remained in North Africa, where it diversified, and afterward dispersed to the Canary Islands $(+B)$. Sanmartín \& Martín-Piera (2003) showed that the endemic Canarian species of Pachydema do not form a monophyletic lineage within the genus. In Fig. 2, P. castanea (Brullé, 1838) and $P$. bipartita (Brulle, 1838) are more closely related to the 
African $P$. anthracina Fairmaire, 1860 than to the Canarian P. obscura (Brullé, 1838) and P. tinerfensis Galante \& Stebnicka, 1992. DIVA optimal reconstructions (Fig. 3) show that dispersal to the Canary Archipelago $(+\mathrm{B})$ occurred at least two times from different African ancestors, followed by backward dispersal to North Africa $(+\mathrm{A})$. This independent origin of the Canarian species from different African ancestors contrasts with the traditional 'Hawaiian' model (one common ancestor radiating through the islands, Simon, 1987) found in other Canarian groups (Thorpe et al., 1993). Because the Canary Islands are of volcanic origin and were probably never connected to the mainland (Juan et al., 2000), dispersal is the most likely explanation for the colonization of the archipelago. This is further supported by the fact that Pachydema is the only known genus of Palearctic Pachydeminae whose females present functional wings (Sanmartín \& Martín-Piera, 2003).

The second North African lineage, i.e. the ancestor of the clade Pachydema rubripennis (Lucas, 1848)-P. excisusHemictenius probably dispersed from North Africa (P. rubripennis) to Sicily $(+\mathrm{I})$, where $P$. excisus originated, and Central Asia $(+\mathrm{H})$, where the stem species of Hemictenius rapidly diversified. Although there is a polytomy in the strict consensus tree (Fig. 2), P. rubripennis in North Africa occupies the basal position of the clade in more than $80 \%$ of the MPTs (Fig. 3), thus supporting a North African origin for the ancestor of P. rubripennis-Peritryssus-Hemictenius. The genus Hemictenius probably originated and diversified in Central Asia, as all species of Hemictenius are now restricted to this region (Table 1 ). The wide disjunction between Hemictenius in Central Asia and P. rubripennis and $P$. excisus in the western Mediterranean region (North Africa and Sicily) is probably the result of either extinction or unknown occurrences of this clade in the intermediate areas, i.e. the Middle East and Iran. Examples of vicariant distributions between the western Mediterranean and the Turanian region (Central Asia) are known in many groups of insects (Ribera \& Blasco-Zumeta, 1998; Martín-Piera \& Sanmartín, 1999). In any case, the split that gave rise to Hemictenius is probably as old as the isolation of the northern Iranian Plateau from Central Asia, which followed the uplift of the Kopet-Dagh Mountains in the early Pliocene, 5 Myr ago (see above).

How to explain the isolation of the remarkable $P$. excisus in Sicily? Sicily is a composite area that was formed during the late Oligocene-Miocene from terranes derived from the Apulian Plate, one of African microplates. Northeast Sicily is composed of early Tertiary terranes (there was a second uplift during the Pleistocene), whereas southwest Sicily is probably of late Tertiary (Oligocene-Miocene) origin (De Jong, 1998). During the late Eocene, the final collision of the Apulian plate with Eurasia initiated the deformation of the western and Corsican Alps. The southeast convergence of Apulia with respect to a more or less stable Europe led to the arise of the 'late Oligocene Alpine system', formed by the western Alps, the Betic-Rif chain, the Balearic massif, the Corsica-Sardinia block, southern Sicily, the Peloritan-Calabrian massif of southern Italy, and the Kabylies. This system was progressively fragmented during the late Tertiary by the formation of extensional marine basins in the western Mediterranean (De Jong, 1998). During the early Miocene (20 Myr), the Kabylie-Calabria block (including Sicily) became separated from the Rif-Betic-Balearic belt, and started moving southeastward, opening the South Balearic basin. The Kabylies became finally separated from the Peloritan-Calabrian (Sicily) block during the mid-late Miocene (15-7 Myr), eventually colliding with northwest Africa to form the Atlas and Tell Mountains. It is possible that the vicariance event $(\mathrm{AI})$ that separated $P$. excisus in Sicily from the ancestor of the clade in North Africa (A, P. rubripennis) corresponds to the late Miocene separation of the Kabylies (the future northwest Africa) from the Peloritan-Calabrian (Sicily) block. According to Voelker (1999), a land-bridge connection between Sicily and Tunisia existed before the Pleistocene, which could have facilitated faunal exchange between European and African birds. Alternatively, these events could be explained as more recent dispersal during the Pleistocene glaciations, but the atypical morphology of Peritryssus, with numerous apomorphies (Sanmartín \& Martín-Piera, 2003), suggests that the split must be at least pre-Pleistocene.

As for the rest of the strict consensus tree (Fig. 2), the large number of polytomies makes it difficult to draw new inferences. However, several conclusions can be reached. Both the Middle East (E) and the Iran-Afghanistan region $(G)$ have acted as important centres of diversification within Pachydeminae. DIVA optimal reconstructions (Fig. 3) postulate that these regions were the ancestral areas in the basal duplication events that gave rise to many of the least speciose genera of Pachydeminae (e.g. Atanyproctus, Otoclinius, Leptochristina).

There have been several dispersal events from Iran (area $\mathrm{G})$ into the Caucasus region $(\mathrm{F})$ and Central Asia $(\mathrm{H})$, but most of these dispersals occurred at terminal tips (i.e. they are not inferred as ancestral areas at terminal nodes, Fig. 3), indicating that these events correspond to recent range expansions. In fact, except for Pseudopachydema caucasica Balthasar, 1930, all distributions involving the Caucasus region $(\mathrm{F})$ seem to be the result of recent dispersal from Iran $(\mathrm{G}+\mathrm{F})$. There has also been frequent dispersal from Iran to the Middle East (+E, Fig. 3) but most of these dispersal events occurred at internal branches that were later split by vicariance (allopatric speciation) events (EG, Fig. 3). One of these speciation events within the Iran-Afghanistan region $(\mathrm{G})$ is probably responsible for the origin of the clade P. zhora Normand, 1951; Otoclinius fragilis Petrovitz, 1980; Europtron gracile Marseul, 1867, and the monotypic genera Brenskiella and Alaia. Diversification within this heterogeneous clade (Sanmartín \& Martín-Piera, 2003) presumably involved dispersal to North Africa and the Middle East region ( $+\mathrm{A}+\mathrm{E}$ ), followed by vicariance (Fig. 3).

The ancestor of the clade Tanyproctoides, Leptochristina, Elaphocera, and Ceramida originated in the Middle East region (E) by sympatric speciation, probably after dispersal from Iran, the original distribution of O. gracilipes Brenske, 1896 (but the position of this species is not resolved in the 
strict consensus, Fig. 2). Successive duplication events within the Middle East gave rise to several genera: the monotypic genus Tanyproctoides, the (probably) paraphyletic genus Leptochristina (Sanmartín \& Martín-Piera, 2003), and the ancestor of Elaphocera and Ceramida.

The DIVA ancestral area reconstructions suggest that the ancestor of Elaphocera -Ceramida dispersed at some point from the Middle East (E) to North Africa (+A), the Balkans/ Anatolian region $(+D)$, and the western Mediterranean $(+C)$, although the sequence of dispersal events is not clear because there are several possible reconstructions (Fig. 3). These dispersals were followed by a basal vicariance event that isolated the ancestor of E. barbara-Ceramida in the North Africa-western Mediterranean region (AC) from the stem species of Elaphocera in the Middle East (E), or alternatively in the Middle East and the eastern/western Mediterranean region (EC/ED/ECD). The basal position occupied by E. syriaca in the phylogeny (Fig. 3) supports the assumption that the Middle East region was probably the ancestral distribution of Elaphocera. Subsequent diversification within Elaphocera involved several dispersal events followed by vicariance between the east and west Mediterranean $(\mathrm{E} / \mathrm{D} / \mathrm{C})$, and between the western Mediterranean and North Africa (A/C). However, this sequence of dispersal events is not clear because there are several alternative solutions for each node in the optimal reconstruction (see Fig. 3).

As pointed out above, evolution within the clade Elaphocera-Ceramida-E. barbara involved multiple dispersalvicariance events between the eastern Mediterranean (Middle East/Balkans-Anatolia, DE) and the western Mediterranean regions (AC), including southern Iberia, the Balearic Islands, Sardinia, and northwest Africa (MoroccoAlgeria). This east-west exchange occurred at the basal split between Ceramida-E. barbara and Elaphocera, but also within the phylogeny of Elaphocera. Dispersal from the east to the west Mediterranean could have taken place via two different routes. The ancestor of Elaphocera and Ceramida could have dispersed from the east to the west Mediterranean across Europe, entering the Iberian Peninsula from the north, and later dispersing to North Africa. Paleogeographical reconstructions show that terrestrial dispersal across Europe between the East and West Mediterranean was possible at different times during the late OligoceneMiocene, following the establishment of a continuous landmass connection after Tethys-Paratethys marine regressions (Rögl \& Steininger, 1983). According to Oosterbroek \& Arntzen (1992), these connections allowed biotic dispersal throughout the Mediterranean, and gave rise to the ancestors of trans-Mediterranean lineages. Alternatively, the ancestor of Elaphocera-Ceramida could have dispersed to the western Mediterranean across North Africa, entering the Iberian Peninsula from the south. The first possibility, European dispersal and colonization from the north, appears to be less likely for two reasons. First, the distributions of Elaphocera and Ceramida in the northern part of the Mediterranean region are restricted to the southern half of the Iberian and Balkan Peninsulas, indicating that both the
Iberian Central Plateau and the Balkans probably acted as barriers to dispersal for Pachydeminae. Second, during the late Tertiary, several geological barriers could have limited dispersal across Europe. For example, the Pyrenees isolated the Iberian Peninsula from the rest of Europe during most of the Tertiary. These mountains were formed at the end of the Cretaceous as a result of the collision of the Iberian Plate with Eurasia, partially eroded during the Oligocene-Miocene, and uplifted again in the early Pliocene, $5 \mathrm{Myr}$ ago (Oosterbroek \& Arntzen, 1992; De Jong, 1998). On the other hand, final restructuring of the Alps/Central Italy in the late Miocene-Pliocene probably acted as another barrier to dispersal across Europe (Dercourt et al., 1986; De Jong, 1998). No Pachydeminae is presently found in the Central Mediterranean region, including the Italian Peninsula and southern France.

In contrast, dispersal from the south across Africa could have been possible at the end of the Miocene during the so-called 'Messinian salinity crisis' (Krijgsman, 2002). In the late Miocene, the differential collapse of the Betic-Rif Belt resulted in the origin of the Gibraltar arc, and the almost complete closing of the Mediterranean Sea from the Atlantic Ocean. As a result, during the Messinian age (7-5.3 Myr), the Mediterranean experienced a massive evaporation and shrank, turning into a shallow hypersaline basin (De Jong, 1998). The Red Sea became also partially dried during this period (6.5-5 Myr), allowing biotic connections in the north between the African and Arabian Plates (Thompson, 2000). These connections, which lasted until 3.5-3 Myr, could have allowed dispersal of West Asian groups to North Africa during the late Miocene (Cheylan, 1995). North African dispersal was also probably favored by the climatic alternance of relatively humid phases with hyper-arid phases in the Saharan and Arab-Syrian deserts during the mid-PliocenePleistocene (3 Myr) (Quezel \& Barbero, 1993; Thompson, 2000). Therefore, the ancestors of Elaphocera and Ceramida could have dispersed from the Middle East to North Africa across the Red Sea during the late Miocene, and later dispersed to the Iberian Peninsula across the Gibraltar Strait during the partial desiccation of the Mediterranean in the Messinian. According to Krijgsman (2002), before the late Miocene, dispersal between North Africa and the Iberian Peninsula was prevented by the existence of two water corridors connecting the Atlantic to the Mediterranean: the 'Betic Corridor' through southern Spain and the 'Rifian Corridor' through northern Morocco. Although the first corridor was closed around the Tortonian (11-7 Myr), the 'Rifian' corridor remained opened until the Messinian salinity crisis, 6.0 Myr ago. The Messinian salinity crisis ended when the present-day Gibraltar Strait opened at the start of the Pliocene $(5 \mathrm{Myr})$, restoring the connections between the Mediterranean and the Atlantic. This event can probably account for the vicariance between North African/ Iberian lineages observed in the split E. barbara/Ceramida (Fig. 3), as well as in many other Mediterranean lineages (Martín-Piera \& Zunino, 1983, 1985; Doadrio, 1990; Doadrio et al., 1998; Zardoya \& Doadrio, 1998; MartínPiera \& Sanmartín, 1999). 


\section{CONCLUSIONS}

The DIVA optimal reconstructions suggest that the ancestor of the Palearctic Pachydeminae was originally present in the south-east Mediterranean region, including North Africa, the Middle East, the Iranian Plateau, and the Balkans/Anatolian region. Basal splitting within the subfamily was caused by vicariance events related to the late Tertiary collision of the African microplates Apulia and Arabia with Eurasia, and the resultant arise of successive dispersal barriers (e.g. the Red Sea, the Zagros Mountains). Genera like Pachydema or Hemictenius probably originated in this way. Subsequent diversification within Pachydeminae involved multiple speciation events within the Middle East and IranAfghanistan regions, which seem to have acted as centres of diversification in the subfamily. Many of the least speciose Palearctic genera (e.g. Otoclinius, Leptochristina) originated within these two regions by duplication (within-area speciation) events. In contrast, the presence of Pachydeminae in the western Mediterranean region (Iberian Peninsula and south-western Mediterranean Islands) is probably the result of a recent dispersal event. The ancestor of the Iberian genera Elaphocera and Ceramida probably dispersed from the Middle East to the Iberian Peninsula across North Africa and the Gibraltar Strait. This dispersal could have taken place during the 'Messinian salinity crisis' at the end of the Miocene, when the Red Sea and the Mediterranean partially dried up, allowing a short period of biotic dispersal between West Asia, North Africa, and the Iberian Peninsula.

\section{The North African dispersal route}

Comparison of the biogeographical reconstruction in Fig. 3 with previous studies on Mediterranean biogeography (Oosterbroek \& Arntzen, 1992; De Jong, 1998) shows that the main difference lies in the position occupied by the Iberian Peninsula in the cladogram. According to Oosterbroek \& Arntzen (1992), basal lineages in Circum-Mediterranean taxa are mainly restricted to the West Mediterranean (the Iberian Peninsula), whereas more recent lineages are present in the East Mediterranean. This agrees with paleogeographical reconstructions, which show that the western Mediterranean region (including the Iberian Plate) was already part of Eurasia at the beginning of the Tertiary, whereas the eastern Mediterranean is of more recent origin (Dercourt et al., 1986; Krijgsman, 2002).

In contrast, in Pachydeminae (Fig. 3) and De Jong's (1998) study, the Iberian Peninsula occupies a more derived position in the cladogram, suggesting that this area of distribution is the result of a more recent dispersal event from the ancestral area. Also, in both reconstructions, North Africa is placed basally, as part of the ancestral distribution of the group. According to Oosterbroek \& Arntzen (1992), groups with Asia Minor-trans-Mediterranean lineages (e.g. the clade Elaphocera-Ceramida, Fig. 3) are probably younger than those with basal lineages in the Iberian Peninsula, and might be of African origin. It is, therefore, possible that two patterns, both showing circum-Mediterranean area relationships but of different age, are present in the Mediterranean region (a characteristic of 'reticulate' scenarios). The oldest pattern is probably of early Tertiary age (Oosterbroek \& Arntzen, 1992) and corresponds to groups with basal lineages in the Iberian Peninsula and the western Mediterranean. Trans-Mediterranean (east-west) distributions in these groups were presumably achieved by dispersal across Europe, via the landmass connection across the Mediterranean that was established at various times during the late Oligocene-Miocene (Rögl \& Steininger, 1983; Oosterbroek \& Arntzen, 1992). The second pattern (late Tertiary age?) corresponds to groups with more derived lineages in the Iberian Peninsula, and basal lineages in North Africa-West Asia. In these groups, trans-Mediterranean distributions were presumably achieved via dispersal across North Africa, probably during the Messinian salinity crisis at the end of the Miocene. This is probably the case of Pachydeminae. Relationships between western and eastern Mediterranean disjuncts are traditionally explained by dispersal through Central Europe, but this work corroborates recent biogeographical studies that point out North Africa as an alternative dispersal route by which Mediterranean taxa could have achieved circum-Mediterranean (east-west) distributions (Martín-Piera \& Zunino, 1983,1985; Doadrio, 1990; Doadrio et al., 1998; Zardoya \& Doadrio, 1998; Martín-Piera \& Sanmartín, 1999).

\section{Dispersal vs. vicariance}

Basal diversification of the subfamily Pachydeminae around the Mediterranean appears to have been caused by vicariance events linked to the geological formation of the present Mediterranean geography. Vicariant division of a widespread ancestral area by successive geographical barriers (e.g. Red Sea, Zagros Mountains) is the most parsimonious explanation for ancestral distributions at basal nodes in the phylogeny. However, dispersal has also played an essential role in shaping present distribution patterns in the subfamily. DIVA optimal reconstructions required 23 dispersal events, five of which occurred within terminal branches. Because there are 48 internal nodes in the phylogeny, this means that nearly $38 \%$ of the speciation events in Pachydeminae resulted from dispersal to a new area followed by allopatric speciation between lineages (and often by sympatric speciation within each lineage). Given that the Pachydeminae are poor dispersers (females are flightless), it is surprising that dispersal has been so important in shaping their present distribution patterns. It further emphasizes the importance of explicitly considering dispersal in biogeographical reconstructions (especially in 'reticulate' biogeographical scenarios).

\section{ACKNOWLEDGMENTS}

This work was supported by the European Union through the Marie Curie Fellowship Program (project MCFI-200000794). 


\section{REFERENCES}

Brooks, D.R. (1990) Parsimony analysis in historical biogeography and coevolution: Methodological and theoretical update. Systematic Zoology, 39, 14-30.

Browne, D. \& Scholtz, C. (1999) A phylogeny of the families of Scarabaeoidea (Coleoptera). Systematic Entomology, 24, 5184.

Cheylan, M. (1995) Les reptiles du Paléartique occidental. Diversité et Conservation. Doctoral dissertation (unpublished), Laboratoire de Biogéographie et Ecologie des Vertébrés, Montpellier. 339 pp.

Cox, C.B. (2001) The biogeographic regions reconsidered. Journal of Biogeography, 28, 511-523.

De Jong, H. (1998) In search of historical biogeographic patterns in the western Mediterranean terrestrial fauna. Biological Journal of the Linnean Society, 65, 99-164.

Dercourt, J., Zonenshain, L.P., Ricou, L.E., Kazmin, V.G., Le Pichon, X., Knipper, A.L., Grandjacquet, C., Sbortshikov, I.M., Geyssant, J., Lepvrier, C., Pechersky, D.H., Boulin, J., Sibuet, J.C., Savostin, L.A., Sorokhtin, O., Westphal, M., Bazhenov, M.L., Lauer, J.P. \& Biju-Duval, B. (1986) Geological evolution of the Tethys belt from the Atlantic to the Pamirs since the Lias. Tectonophysics, 123, 241-315.

Dewey, J., Pitman, W.C., Ryan, W.B.F. \& Bonnin, J. (1973) Plate tectonics and the Evolution of the Alpine System. Geological Society of America Bulletin, 84, 3137-3180.

Doadrio, I. (1990) Phylogenetic relationships and classification of western Palaearctic species of the genus Barbus (Osteichthyes, Cyprinidae). Aquatic Living Resources, 3, 265-282.

Doadrio, I., Bouhadad, R. \& Machordom, A. (1998) Genetic differentiation and biogeography in Saharan populations of the genus Barbus (Osteichthyes, Cyprinidae). Folia Zoologica, 47, 41-57.

Harold, A.S. \& Mooi, R.D. (1994) Areas of endemism: definition and recognition criteria. Systematic Biology, 43, 261-266.

Juan, C., Emerson, B.C., Oromí, P. \& Hewitt, G.M. (2000) Colonization and diversification: towards a phylogeographic synthesis for the Canary Islands. Trends in Ecology and Evolution, 15, 104-109.

Krijgsman, W. (2002) The Mediterranean: Mare Nostrum of Earth sciences. Earth and Planetary Science Letters, 205, $1-12$.

Lacroix, M. (2000) Hannetons, un monde de diversité. Website: http://hannetons.free.fr.

Linder, H.P. (2001) On Areas of endemism, with an example from the African Restionaceae. Systematic Biology, 50, 892912.

Macey, J.R., Schulte, J.A. II, Ananjeva, N.B., Larson, A., Rastegar-Pouyani, N., Shammakov, S.M. \& Papenfuss, T.J. (1998) Phylogenetic relationships among Agamid lizards of the Laudakia caucasia species group: testing upothesis of biogeographic fragmentation and an area cladogram for the Iranian Plateau. Molecular Phylogenetics and Evolution, 10, 118-131.

Martín-Piera, F. \& Zunino, M. (1983) Amphionthophagus, nuovo sottogenere di Onthophagus Latr. (Coleoptera, Scarabaeidae). Bulletin di Museo Regionali di Scienzia Naturali di Torino, 1, 59-76.
Martín-Piera, F. \& Zunino, M. (1985) Taxonomie et biogeographie des Ontophagus du groupe d l'O. ovatus I. (Coleoptera, Scarabaeoidea). Nouvelle Revue d'Entomologie (NS), 2, 241-250.

Martín-Piera, F. \& Sanmartín, I. (1999) Biogeografía de áreas y biogeografía de artrópodos Holárticos y Mediterráneos. Evolution and Phylogeny of Arthropoda (ed. by A. Melic, J.J. De Haro, M. Méndez \& I. Ribera), pp. 535-560. Boletín SEA, 26. Sociedad Entomológica Aragonesa, Zaragoza, Spain.

Morrone, J.J. (2002) Biogeographical regions under track and cladistic scrutiny. Journal of Biogeography, 29, 149-152.

Morrone, J.J. \& Crisci, J.V. (1995) Historical biogeography: introduction to methods. Annual Review of Ecology and Systematics, 26, 373-401.

Nelson, G.J. \& Platnick, N.I. (1978) A method of analysis for historical biogeography. Systematic Zoology, 27, 1-16.

Noonan, G. (1988) Biogeography of North American and Mexican insects, and a critique of vicariance biogeography. Systematic Zoology, 37, 366-384.

Nordlander, G., Zhiwei, L. \& Ronquist, F. (1996) Phylogeny and historical biogeography of the cynipoid wasp family Ibaliidae (Hymenoptera). Systematic Entomology, 21, 151-166.

Oosterbroek, P. \& Arntzen, J.W. (1992) Area cladograms of Circum-Mediterranean taxa in relation to Mediterranean palaeogeography. Journal of Biogeography, 19, 3-20.

Page, R.D.M. (1994) Maps between trees and cladistic analysis of relationships among genes, organisms, and areas. Systematic Biology, 43, 58-77.

Page, R.D.M. (1995) Parallel phylogenies: reconstructing the history of host-parasite assemblages. Cladistics, 10, 155-173.

Por, F.D. (1975) An outline of the zoogeography of the Levant. Zoologica Scripta, 4, 5-20.

Quezel, P. \& Barbero, M. (1993) Variations climatiques au Sahara et en Afrique sèche depuis le Pliocene: enseignements de la flore et de la végétation actuelles. Bulletin du Ecologie, 24, 191-202.

Ribera, I. \& Blasco-Zumeta, J. (1998) Biogeographical links between steppe insects in the Monegros region (Aragón, NE Spain), the eastern Mediterranean, and central Asia. Journal of Biogeography, 25, 969-986.

Ronquist, F. (1996) DIVA v. 1.1. Computer program for MacOS and Win32. Available from (http://morphbank.ebc. uu.se/DIVA).

Ronquist, F. (1997) Dispersal-vicariance analysis: a new approach to the quantification of historical biogeography. Systematic Biology, 46, 195-203.

Ronquist, F. (1998) Phylogenetic approaches in coevolution and biogeography. Zoologica Scripta, 26, 313-322.

Ronquist, F. (2002) Parsimony analysis of coevolving species associations. Cospeciation (ed. by R.D.M. Page), pp. 22-64. Chicago University Press, Chicago, IL.

Rögl, F. \& Steininger, F.F. (1983) Von Zerfall der Tethys zu Mediterran und Paratethys. Die neogene Palaeogeographie und Palinspastik des zirkum-mediterranen Raumes. Annals Naturhistorisch Museum Wien (A), 85, 135-163.

Sanmartín, I., Enghoff, H. \& Ronquist, F. (2001) Patterns of animal dispersal, vicariance and diversification in the Holarctic. Biological Journal of the Linnean Society, 73, 345-390. 
Sanmartín, I. \& Ronquist, F. (2002) New solutions to old problems: widespread taxa, redundant distributions, and missing areas in event-based biogeography. Animal Biodiversity and Conservation, 25, 75-93.

Sanmartín, I. \& Martín-Piera, F. (2003) First phylogenetic analysis of the subfamily Pachydeminae (Coleoptera, Scarabaeoidea, Melolonthidae): the Palearctic Pachydeminae. Journal of Zoological Systematics and Evolutionary Research 41, 2-46.

Sanmartín, I. \& Ronquist, F. (in press) Southern Hemisphere Biogeography: Plant vs. Animal Patterns. Systematic Biology.

Simon, C. (1987) Hawaiian evolutionary biology: an introduction. Trends in Ecology and Evolution, 7, 175-178.

Smith, A.G., Smith, D.G. \& Funnel, B.M. (1994) Atlas of Mesozoic and Cenozoic Coastlines, 99 pp. Cambridge University Press, Cambridge.

Thompson, A. (2000) Origins of Arabia. Oriental Press, Dubai.

Thorpe, R.S., MacGregor, D.P., Cumming, A.M. (1993) Molecular phylogeny of the Canary Islands lacertids Gallotia: mitochondrial DNA restriction fragment divergence in relation to sequence divergence and geological time. Journal of Evolutionary Biology, 6, 725-735.

Voelker, G. (1999) Dispersal, vicariance, and clocks: historical biogeography and speciation in a cosmopolitan passerine genus (Anthus: Motacillidae). Evolution, 53, 1536-1552.

Voelker, G. (2002) Systematics and historical biogeography of wagtails: dispersal versus vicariance revisited. The Condor, 104, 725-739.
Waters, J.M., López, J.A. \& Wallis, G.P. (2000) Molecular phylogenetics and biogeography of galaxiid fishes (Osteichthyes: Galaxiidae): Dispersal, vicariance, and the position of Lepidogalaxias salamandroides. Systematic Biology, 49, 777-795.

Zardoya, R. \& Doadrio, I. (1998) Phylogenetic relationships of Iberian cyprinids: systematic and biogeographical implications. Proceedings of the Royal Society of London B, 265, 1365-1372.

\section{BIOSKETCH}

Isabel Sanmartín works as Assistant Professor at the Department of Systematic Zoology (Uppsala University). Her research interests include the study of historical biogeographical patterns at continental scale using large data sets of organism phylogenies (Biol. J. Linn. Soc., 73: 345-390; Syst. Biol., in press), and the development and application of the 'event-based' approach to historical biogeography (Anim. Biodivers. Conserv., 25: 73-95). She presently works on a project to study colonization patterns in the Canary Islands. 
Appendix Species included in the biogeographical analysis and their main geographical distribution. Adapted from Sanmartín $\&$ Martín-Piera (2003)

\begin{tabular}{|c|c|c|}
\hline Genus & Species & Geographical distribution \\
\hline \multirow[t]{2}{*}{ Otoclinius Brenske, 1896} & O. fragilis Petrovitz, 1980 & Iran \\
\hline & O. gracilipes Brenske, 1896 & Iran \\
\hline Pachydemocera Reitter, 1902 & P. lucidicollis (Kraatz, 1882) & Rhodes, Syria \\
\hline \multirow[t]{2}{*}{ Leptochristina Baraud \& Branco, 1991} & L. pubimargo (Reitter, 1902) & Syria \\
\hline & L. annamariae Baraud \& Branco, 1991 & Iraq \\
\hline \multirow{9}{*}{ Tanyproctus Faldermann, 1835} & T. (B.) reichei (Rambur, 1843) & Greece; Asia Minor \\
\hline & T. (T.) rufidens (Marseul, 1879) & Iran, Caucasus \\
\hline & T. (B.) kindermanni (Reiche, 1861) & Syria, Israel \\
\hline & T. (T.) bucharicus (Reitter, 1897) & Afghanistan, Tajikistan \\
\hline & T. (T.) subciliatus Reitter, 1902 & Afghanistan, Turkmenistan \\
\hline & T. (Tca.) saulcyi (Reiche, 1856) & Israel; Syria \\
\hline & T. (B.) rugulosus Fairmaire, 1892 & Syria \\
\hline & T. (T.) ganglbaueri (Brenske, 1897) & Iran \\
\hline & T. (T.) persicus (Ménétries, 1832) & Iran, Caucasus \\
\hline \multirow[t]{10}{*}{ Pachydema Castelnau, 1832} & P. castanea (Brullé, 1838) & Canary Islands \\
\hline & P. obscura (Brullé, 1838) & Canary Islands \\
\hline & P. bipartita (Brullé, 1838) & Canary Islands \\
\hline & P. tinerfensis Galante \& Stebnicka, 1992 & Canary Islands \\
\hline & P. (A.) anthracina Fairmaire, 1860 & Morocco \\
\hline & P. (P.) hirticollis (Fabricius, 1787) & Algeria; Tunis; Libya \\
\hline & P. (P.) xanthochroa Fairmaire, 1879 & Tunis \\
\hline & P. (S.) palposa Reitter, 1902 & Egypt \\
\hline & P. (A.) rubripennis (Lucas, 1848) & Morocco; Algeria \\
\hline & P. (A.) zohra Normand, 1951 & Tunis; Libya \\
\hline \multirow[t]{6}{*}{ Hemictenius Reitter, 1897} & H. tekkensis (Reitter, 1889) & Trans-Caspian; Turkmenistan \\
\hline & H. ochripennis Reitter, 1902 & Tajikistan \\
\hline & H. opacus (Ballion, 1870) & Turkmenistan, Tajikistan \\
\hline & H. simplicitarsis Reitter, 1897 & Tajikistan \\
\hline & H. opacipes Reitter, 1902 & Buchara, Uzbekistan \\
\hline & H. nigrociliatus Reitter, 1897 & Buchara, Uzbekistan \\
\hline \multirow[t]{8}{*}{ Elaphocera Gené, 1836} & E. elongata Schauffus, 1874 & Greece; Turkey \\
\hline & E. syriaca Kraatz, 1882 & Syria \\
\hline & E. emarginata (Gyllenhal, 1817) & Sardinia \\
\hline & E. capdeboui Schauffus, 1882 & Balearic Islands \\
\hline & E. barbara Rambur, 1843 & Morocco; Algeria \\
\hline & E. sulcatula Fairmaire, 1884 & Morocco \\
\hline & E. carteiensis Rambur, 1843 & SE Iberian Peninsula \\
\hline & E. alonsoi López-Colón, 1992 & SE Iberian Peninsula \\
\hline \multirow[t]{2}{*}{ Ceramida Baraud, 1987} & C. bedeaui (Erichson, 1840) & S. Iberian Peninsula \\
\hline & C. baraudi (Branco, 1981) & Portugal \\
\hline Europtron Marseul, 1867 & E. gracile Marseul, 1867 & Algeria \\
\hline Peritryssus Reitter, 1918 & P. excisus Reitter, 1918 & Sicilia \\
\hline Brenskiella Berg, 1898 & B. flavomicans (Brenske, 1896) & Israel \\
\hline Alaia Petrovitz, 1980 & A. sexdentata Petrovitz, 1980 & Iran; Afghanistan \\
\hline Tanyproctoides Petrovitz, 1971 & T. arabicus (Arrow, 1932) & Saudi Arabia \\
\hline \multirow{2}{*}{ Atanyproctus Petrovitz, 1954} & A. miksici Petrovitz, 1965 & Afghanistan \\
\hline & A. simplicitarsis Petrovitz, 1954 & Iran \\
\hline Pseudopachydema Balthasar, 1930 & P. caucasica Balthasar, 1930 & Caucasus \\
\hline Kryzhanovskia Nikolajev \& Kabakov, 1977 & K. olegi Nikolajev \& Kabakov, 1977 & Afghanistan \\
\hline
\end{tabular}

